\title{
The Dialectic of Contemporary Thought of The Muhammadiyah Economic Movement
}

\author{
Imamul Hakim \\ Department Of Islamic Economics University Of Muhammadiyah Malang \\ Email:imamulhakimhakim@gmail.com
}

\begin{abstract}
Muhammadiyah is one of the largest religious organization in Indonesia that has stood more than a century and became an organization with the world's greatest asset, however up to now Muhammadiyah still does not have a definite format of economic movement. The dialectic of Muhammadiyah economic movement remains a fascinating debate. This study aims to examine the ideas of Muhammadiyah's economic format that have been outlined by Muhammadiyah figures, experts, and scholars in the form of writing to look for the intersection of thought into a single entity the main idea of Muhammadiyah Economic Format. This research using the method of the library research with the source data that is be retrieved from the secondary data that have been written by scholars, scientists, and experts of the Muhammadiyah economic movement have ever written about the format of Muhammadiyah economic movement. The results show that there are three groups of main ideas about the format of the Muhammadiyah economic movement, that is; Firstly, Incorporated Movement, is incorporated in the management merger business which it strengthened networking either in vertical or horizontally. Secondly, Community economic empowerment movement, This movement emphasizes full structural involvement in economic empowerment by providing information on market opportunities, capital, business training, financial management and making business innovations. Thirdly, the Comprehensive Economic Movement, namely; the Economic Movement that integrates Incorporated and Empowerment. Muhammadiyah's economic movement needs to be built in two directions by combining Incorporated and Empowering, through structuring and merging Muhammadiyah's business entities with economic empowerment of Muhammadiyah citizens.
\end{abstract}

Keywords: Muhammadiyah Economic Movement, Incorporated, Empowerment

\begin{abstract}
Abstrak
Muhammadiyah adalah salah satu organisasi keagamaan yang terbesar di Indonesia yang telah berdiri lebih dari satu abad dan menjadi organisasi dengan aset terbesar di dunia, namun hingga kini Muhammadiyah masih belum memiliki format gerakan ekonomi yang pasti. Dialektika tentang format ekonomi Muhammadiyah masih menjadi perdebatan menarik. Penelitian ini bertujuan mengkaji berbagai ide pemikiran format ekonomi Muhammadiyah yang telah dituangkan oleh para tokoh, pakar dan cendekiawan Muhammadiyah dalam bentuk tulisan untuk dicari titik temu dari berbagai pemikiran tersebut menjadi satu kesatuan ide pokok format ekonomi Muhammadiyah. Penelitian ini menggunakan metode penelitan kepustakaan (library research) dengan sumber data skunder yang akan didapat dari karya yang telah ditulis oleh para cendekiawan, ilmuwan dan para pakar ekonomi kontemporer Muhammadiyah yang pernah menulis tentang format gerakan ekonomi Muhammadiyah. Hasil dalam penelitian mendapati tiga kelompok ide pokok pemikiran format gerakan ekonomi Muhammadiyah, yaitu; pertama, Gerakan Incorporated, yang dimaksud Incorporated adalah usaha penggabungan manajemen dalam menguatkan jaringan baik secara vertical maupun horizontal. Kedua Gerakan Pemberdayaan ekonomi masyarakat, gerakan ini menekankan keterlibatan structural secarah penuh dalam pemberdayaan ekonomi dengan memberikan informasi peluang pasar, permodalan, pelatihan bisnis, pengelolaan keuangan dan membuat inovasi-inovasi bisnis. ketiga Gerakan Ekonomi Komprehensif, yaitu; gerakan ekonomi yang mengintegrasikan antara incorporated dan pemberdayaan. Gerakan ekonomi
\end{abstract}


Muhammadiyah perlu dibangun melalui dua arah dengan mengintegrasikan antara incorporated dan pemberdayaan, melalui penataan dan penggabungan badan usaha milik Muhammadiyah dengan pemberdayaan ekonomi warga Muhammadiyah.

Kata Kunci : Gerakan Ekonomi Muhammadiyah, Incorporated, Pemberdayaan

\section{INTRODUCTION}

As a large country, the Indonesian people have abundant natural resources, a strategic geographical location and homogeneous sociocultural reasons should be able to become a strong nation in all fields, especially in the economic area. However, this potential has not been able to make this nation out of the downturn, poverty, social disparities that are increasingly depressing and the complexity of various social problems that are getting worse and worse. While, the State by changing different regimes has not been able to remove this nation from its slump and its various issues. On the other hand, Muhammadiyah as one of the largest organizations in Indonesia has had an enormous contribution to this country. Muhammadiyah has provided programs that have a significant influence on community empowerment, especially in the field of education and health. Muhamadiyah has shown its work for enlightenment and progress that gives benefit to the people as a manifestation of Da'wah Amar ma'ruf Nahi Mungkar. However, this is very contrary to the role of Muhammadiyah in economic development.

Until now, As a Religious Social Organization, Muhammadiyah has had the largest asset in the World. The number of assets owned by Muhammadiyah to date is more than 9,000 educational institutions ranging from PAUD to high school, 67 boarding schools, 171 universities, 2000 more hospitals / medical centers, 500 more orphanages, nursing homes and extraordinary schools, 11,000 more Mosques/ Mushollah and land covering 20,945,504 $\mathrm{M}^{2}$ which has been certified in the name of Muhammadiyah, and many more that have not been recorded. Not to mention, the business assets developed by each business charity that has not been calculated, such as gas stations, mineral water companies, and others, whether they purely owned by
Muhammadiyah or run through partnerships with their members. With assets that are so large, it becomes a problem in itself, where Muhammadiyah is required to be more progressive especially in managing its business charity, both for non-profit business, and profit.

The role of Muhammadiyah in the social and religious fields especially in the field of education has given considerable benefits to this country. However, in its movement, Muhammadiyah was unable to provide benefits (if not less concerned) about the economic conditions of oppressed groups such as the workers, farmers, small traders and especially the urban poor living under the feasibility of collecting sustenance from singing, begging or scavenging. On the other hand, the thing we need to realize is that we are too complacent with the assumption that Muhammadiyah is the middle-class urban group. However, social reality shows another. Whereas, along with the development of Muhammadiyah for more than a century, it is currently flourishing among the rural areas dominated by the poor who have difficulties in obtaining jobs, adequate health, and education services and even challenges in obtaining daily necessities. It is the demand for Muhammadiyah to formulate its economic movement. Where exactly are the Muhammadiyah economic movements?

$$
\text { According to Karim, (1995) }
$$

Muhammadiyah should not sink into the flow of marginalization of roles. On the contrary, it could further strengthen its commitment to always be at the forefront in all phases of community development in the direction of industrial order in the future. Identity as an initiator of an innovative movement that used to be the main characteristic of Muhammadiyah must be more actualized if Muhammadiyah wants to remain a force for community renewal. Sasono, (1995) added that Muhammadiyah must sharply see the interaction between economic dynamics 
and the da'wah movement are inseparable from one another. Because to answer more relevant challenges caused by global world phenomena, there need to be strategic steps to review and put in place strategies that are more appropriate in the context of economic dynamics. Meanwhile Birton, (2010) considers that if ijtihad and Tajdid al-Maun only rely on and revolve around philanthropic concepts and practices. Whereas, looking at the challenges of the economic future, what is needed is a formulation patent of the Muhammadiyah Economic Movement, which includes the macroeconomic and microeconomic and social development.

In reality, Muhammadiyah still does not have a specific economic movement format. Dialectics about the Muhammadiyah economic movement format is always an interesting debate. Not to mention the refusal of some people who held the view that Muhammadiyah was a Religious Social Organization engaged in the field of da' wah and social assistance that was not intended to gain profit only, while activities that were oriented to profit activities were deemed unfit to be carried out by Religious Social Organization (Asy'Arie, 2000), because it is considered contradictory to the values of morality and da'wah itself. That religious activities are purely social activities and not aimed at taking advantage of both individuals and organizations. Besides, there are concerns that business activities can reduce the da' wah activities of the organization itself and diminish the goal in the da' wah so that da' wah activities are considered impure and contaminated by worldly objectives. Whereas removing the people from slavery and destitution is one of the tasks for Muhammadiyah as aspired by the founders of the Persyarikatan. Besides, as an Islamic organization, Muhammadiyah must be able to manifest the messages in the Qur'an and the Hadith in solving the realities of people's lives in real, so that the presence of religion in the community can be felted. Muhammadiyah Persyarikatan needs to think professionally about its economic movement, through the use of its owned market, so that it becomes the center of the people's economic empowerment movement (Asy'Arie, 2000). Looking at the challenges of the economic future, what is needed is a patent formulation of the Muhammadiyah Economic Format which covers the macroeconomic, microeconomic framework and social development (Birton, 2010).

There have been many big ideas in trying to formulate the economic format of Muhammadiyah, since long before this country became independent. K.H. Mas Mansur had made a new breakthrough by planning the establishment of the Muhammadiyah Bank (Mulkhan, 1990). Likewise with Dawam Rahardjo, (2000) Initiating Muhammadiyah's economic management in the "Quantum leap of Muhammadiyah Economics" by basing economic empowerment through four pillars. Until the 46th congress in Yogyakarta, there were two hot topics discussed, namely about Holding Companies and Incorporated (Suryanto, 2010). Besides, there are many leaders, economists, scholars of Muhammadiyah members who have studied and produced various ideas on the economic format of Muhammadiyah in the last few decades, including; M. Amien Rais, Abd. Munir Mulkhan, Sukriyanto, Mas'ud Machfoedz, Musa Asy'Arie, Dawam Rahardjo, Adi Sasono, Bagus Handoko, Anwar Abbas, Mukhaer Pakkanna, Ahmad Juanda, M. Nur A. Birton, Nazaruddin M. Fadjar, Nelly Asnifati, Imam Supriyono, Afghan Andjasmoro, and others. The diversity of these ideas proves a huge demand for the role of Muhammadiyah in the economic development of the people. However, these ideas have not been able to be responded to in the form of concrete actions as a significant and strategic step for Muhammadiyah in realizing the ideals of Muhammadiyah in achieving a just and prosperous the main society that is blessed by Allah SWT.

This study will try to examine various forms of Muhammadiyah's economic format which have been poured by Muhammadiyah figures, experts, and scholars in the form of writing to find common ground for these different thoughts into a single unity the main idea of Muhammadiyah Economic Format.

\section{LITERATURE REVIEW}

In the early days of Muhammadiyah's establishment, many of the Muhammadiyah members consisted of merchants who 
donated zakat, infaq, shadaqah and waqf for organizational development. They are traders from Kotagede, Solo, Pekalongan, and several other trading cities which are the primary sources of organizational development (Baidhawy, 2015a). Muhammadiyah's financial resources are obtained independently, thanks to the voluntary contribution of its members, especially in its operational costs and business charities (Baidhawy, 2015a). As stated by Nakamura, (2012) that the economic activities of merchants go hand in hand with religious activities, because they are inspired by the spirit to get God's pleasure for their financial contributions.

Until now, Muhammadiyah has become the oldest socio-religious organization in Indonesia and has had many business charities in various fields such as Education, Health, Economics, Information and others (Ahmad, 2015). Moreover, the most prominent of the Muhammadiyah movement is in the fields of education, socio-economics, and religious thought (Jinan, 2011). Until now, Muhammadiyah is always consistent in developing the community through education and religious teachings to make enlightenment and empowerment, given the vital role of education in improving the lives of the nation. So, Muhammadiyah has become one of the enlighteners and empowerers for the dignity of this nation (Elhady, 2017).

However, the reality that needs to be understood that from the beginning of its birth, Muhammadiyah had been developed with merchant instincts by its administrators, while in its successor period its leadership was dominated by government employees or employees, so it lacked business sense, so that developed businesses had difficulty developing (Rambe, 2018). This can be seen in several areas of management of Muhammadiyah's business charity experiencing good growth and progress and gaining significant benefits. However, there are also those who stagnate and even suffer bankruptcy which is detrimental to the Persyarikatan (Abdul Mu'in, 2017). NjotoFeillard, (2014) in his research explained that there are indeed various ethical difficulties arising when socio-religious organizations are oriented to profit ventures.
According to Njoto-Feillard, (2014) Initiative of economic movements through modernist organizations in the form of entrepreneurial institutions, in reality, cannot lastlong, as expected. There are several problems, including; competition, macroeconomic factors, and internal management. However, NjotoFeillard, (2014) asserts that this does not apply to Muhammadiyah which is the pioneer of social, religious transformation in Indonesia. Muhammadiyah has fulfilled the material and spiritual needs of the Indonesian people through schools, hospitals, universities, and orphanages. Moreover, now, the issue of entrepreneurship is an important issue that is the subject of debate at Muhammadiyah. According to Baidhawy, (2015), Muhammadiyah through religiousphilanthropic institutions collects and manage zakat, $\square$ adaqah, infāq, waqf, and grants, which are managed transparently and accountable in short-term and long-term programs. Besides, Muhammadiyah also actively advocates for the interests of the poor and needy, who have been victims of structural oppression. All of this based on the spirit of al-mā'ūn theology. Muhammadiyah also always participates in building sustainable business charities.

In its development, Muhammadiyah played a role in modernization by providing solutions to developments in industrialization and technology. In the context of social change, it appears that modernization affects changes in Muslims, but towards better social change (Rahman, 2017). The religious transformation that occurs in three generations shows the validity of the theory that spiritual life is dynamic, dialectical and adaptive to the environment and socio-economic development (Radjasa, 2016). Alexander R. Arifianto, (2017) quoted Haedar Nashir (Muhammadiyah Central Leader) as saying that Islam not only calls on people to worship God but also to manage their affairs. Islam teaches Humans to be proactive actors in promoting various socio-economic change movements. Humans will not be able to change their socio-economic conditions unless the change starts from their own business. Therefore, According to Radjasa, (2016) that what needs to be understood is that socio-religious organization that is unable to adapt to social and economic changes in 
society, will eventually be ignored by the community and its members.

In the relationship between religious life and economic life. Actually Muhammadiyah has proven to have an essential role in transforming religion with the economic reality of the community, as in research results Radjasa, (2016) which examines Muhammadiyah's response to the relationship of religious life and economic life in Indonesia in the tourism sector focused on the Muslim community in Borobudur found that There is a dialectic correlation between economic growth and religious life in the tourism area, which results in the transformation of tourism businesses with religious nuances, which at the same time can create religious activities with economic shades, simultaneously.

In Baidhawy's, (2015b) research argued that one of Muhammadiyah's social ideals in realizing "true Islamic society" was in the economic field, Muhammadiyah had tried to build justice, prosperity, and economic independence through the development of philanthropic movements; in representing themselves as articulators and advocates for the benefit of the poor; and building healthy business activities to realize social welfare. Meanwhile, according to A. Hamid, (2017) in various regions, Muhammadiyah members compete in efforts to manage social welfare by establishing social protection homes such as orphanages for the poor / orphans and also social institutions for neglected parents. It's just that regarding management still not progressing, due to the lack of resources of social workers with scientific disciplines in the field of social welfare.

In the area of economic development of the people, according to Haedar Nasir cited by Alexander R. Arifianto, (2017), Muhammadiyah has a strong commitment in carrying out the vision to improve the social and economic conditions of Indonesian Muslims. Efforts to promote the welfare and social development are the main objectives of Muhammadiyah since its inception in 1912. Although, according to Setyawan, (2013) In the beginning, Muhammadiyah only engaged in socio-religious fields, continued to develop to provide progressive understanding and also played a direct role in the progress of Muslims in Indonesia. With Tajdid and Ijtihad, Muhammadiyah has a role model in fostering business practices under the authority of the Economic and Entrepreneurship Council (MEK) in planning the development and establishment of the Muhammadiyah's business charity (AUM). Because Muhammadiyah already has resources that should not only move in the field of education and socio-religious, but also in the area of business.

According to (Baidhawy, 2015) Muhammadiyah has actually understood its capacity by trying to actively solve economic problems through the mission of its economic movement. As explained by Zulfikar \& Azhar, (2018) that Muhammadiyah has laid the pillars of economic independence as a characteristic of Persyarikatan, and ijtihad continues to manage business charities and establish business units, as stipulated and mandated in the Muhammadiyah Rules of Association (ART). However, along with the development of Muhammadiyah, concrete ideas and strategic ideas are needed to empower Muhammadiyah's citizens. In this case, according to Abdul Mu'in, (2017) also required a guide and training on the management of the Muhammadiyah's business charity that understands the values of Kemuhammadiyahan and Islam as a whole.

According to Baidhawy, (2015a) Until now, Muhammadiyah has made the integration between social entrepreneurship and corporate culture. At first, it emphasized innovation to make social changes, but over time, it was more likely to build an organizational culture in increasing productivity to gain public trust, and also get more benefits to finance the ongoing social activities of the Persyarikatan. This type of business charity chosen for the economic independence of Persyarikatan (self-help, self-financing) have developed into economic institutions.

According to Setyawan, (2017) Muhammadiyah has at least two reasons to develop business in the economic field. First, Muhammadiyah has a belief that managing business in the business sector is no less strategic than the other Muhammadiyah business charities. Second, Muhammadiyah has the resources and potential in working 
on business charities in the Business field. Therefore, Wahyuddin, (2010) asserts that the Muhammadiyah economic movement must be able to optimize in utilizing the factors of production owned by Muhammadiyah. That is, by increasing the human resources of Muhammadiyah citizens, developing entrepreneurial skills of Muhammadiyah citizens and increasing the productivity of asset management owned by Muhammadiyah. The results can be used to improve Muhammadiyah's services and social, economic welfare

Meanwhile, according to Wahjono, (2012) who cited in the Muhammadiyah Bylaws, which explains that Muhammadiyah's efforts in the economic field are: to advance entrepreneurship towards the economy and improve the quality of life ". Likewise the results of the 44th Muhammadiyah Congress in 2000 in Jakarta established work programs in the economy, including 1) forming the Jam'iah system (Muhammadiyah Economic Network) as an overall revitalization of the da'wah movement, 2) Developing ideas and concepts of development-oriented economics and Islamic democracy such as work ethic, entrepreneurial ethics, business ethics, management ethics, finance and capital, etc. according to the actual needs and developments that occur in the world economy. 3) The launch of the program includes empowering human resource development in economic aspects.

\section{RESEARCH METHODS}

This study uses a library research method with a qualitative descriptive approach through sources derived from works written by scholars, scientists, and contemporary economists from Muhammadiyah who have written about the format of the Muhammadiyah Economic Movement in the last few decades, including; M. Amien Rais, Abd. Munir Mulkhan, H.M. Sukriyanto, Mas'ud Machfoedz, Musa Asy'Arie, Dawam Rahardjo, Adi Sasono, Bagus Handoko, Anwar Abbas, Mukhaer Pakkanna, Ahmad Juanda, M. Nur A. Birton, Nazaruddin M. Fadjar, Nelly Asnifati, Imam Supriyono, Afghan Andjasmoro and others, who have created various ideas from the concept of Community Economic Empowerment, Holding Company to Muhammadiyah Incorporated
Researchers want to explore ideas or thoughts from scholars and contemporary Muhammadiyah economists through their works that discuss the economic format of Muhammadiyah contained in books, journals, magazines, and others. From these sources, a thought mapping will be carried out, then grouping ideas and then formulating the Muhammadiyah economic conceptual map.

\section{DISCUSSION}

The economic portrait of Muhammadiyah has been reflected in $\mathrm{KH}$. Ahmad Dahlan. As the founder of Muhammadiyah, he is a warrior figure, Da'i, and trader who has a strong and tenacious work ethic. Besides KH. Ahmad Dahlan, the composition of Muhammadiyah membership in 1916 was dominated by merchants as much as $47 \%$ as much as $47 \%$ and employees $18.1 \%$ and from Ulama elements $12.1 \%$ and the rest from other elements (Abbas \& Anhar, 2010). The administrators are also the average person whose economy is wellestablished and belongs to the puritan Muslim elite. They are rational and independent bourgeois but not selfish. Simple life and a pious work ethic and devote themselves to business and social religious activities at the same time (Juanda, 2010).

In 1937 at the 26th Muhammadiyah congress, K.H. Mas Mansur as chairman of the Muhammadiyah Board made a new breakthrough by planning the establishment of the Muhammadiyah Bank, long before Indonesia's independence (Syahbudi, 2003). The main point of view of Muhammadiyah in the economic field at that time was as follows: (Mulkhan, 1990).

1. To increase the people's economy, capital is needed from the savings of the Ummah that has both individual and institutional advantages.

2. With this capital, a capital forming can be expected. So that, there must be profit. Such benefits can be obtained through cooperatives that work without capital, namely cooperative sales of products, household supplies and savings and loan cooperatives. Muhammadiyah has the main capital that is the sense of unity. Muhammadiyah has labor and 
markets but lacks capital and managers. Therefore, capital forming was needed which was achieved by establishing Bank Muhammadiyah. The institution is the backbone of Muhammadiyah's economy which is carried out with principles without usury.

3. In operating the bank, it can be done, among others:
a. Receive deposits of money by giving profit.
b. Receive deposits of goods with administrative costs.
c. Receive money and goods delivery services and lend money.
d. Establish businesses such as factories, bureaus, plantations, and agriculture.
4. The Bank's capital is obtained from:
a. Fee for one gulden for each member of Muhammadiyah
b. The proceeds of the sale of shares to Muhammadiyah members
c. Looking for savings and capital loans.

However, this big idea had not yet implemented, until in 1985 the 41st Muhammadiyah Congress in Solo was in the form of the Muhammadiyah Economic Assembly. But, this assembly was only tasked with responding to the problems of the National economy as the view of Muhammadiyah. Then at the 43rd Muhammadiyah Conference in Banda Aceh the name of the Economic Assembly was confirmed to be the Economic Development Assembly. From that name, it was concluded that Muhammadiyah began to carry out the mission of empowering the community's economy. (Raharjo, 2000).

In the leadership period of $\mathrm{M}$. Amien Rais, the activities of the Muhammadiyah Economic Development Assembly began to be directed. This is done by compiling a program based on the concept of a particular vision and mission. Basically, the Muhammadiyah Economic Development Assembly (MPEM) will foster the economy of the people through three channels: (1) developing of Muhammadiyah Owned Enterprises (BUMM) which represent Muhammadiyah's economic strength, (2) developing cooperative forums for Muhammadiyah members, and (3) empowering Muhammadiyah members in the economic sector by trying to develop businesses belonging to Muhammadiyah members (Raharjo, 2000).

At the Muhammadiyah Conference in Jakarta in 2000. The desire to take further action in the field of economics became a topic of warm conversation and invited many responses from members and elite leaders of Muhammadiyah. However, it is still limited to discourse. Some BPRs which were initially predicted to be the leading sector for other businesses were also loosened, the existence of which was felt more by the management, even in the elite layer of the organization (M. Fadjar, 2010). At this time Dawam Rahardjo, (2000) initiated the economic management of Muhammadiyah in "Quantum Leap of Muhammadiyah Economy" by basing economic empowerment through four pillars namely; first, the KATAM distribution network (Muhammadiyah Membership Card (Savings)), second, the development of retail and franchise businesses, third, financial institutions and fourth, information technology-based e-commerce.

At the 46th conference in Yogyakarta there were three hot topics discussed, namely; firstly, forming a Holding Company that houses all the charity businesses of Muhammadiyah (holding company). Secondly, establishing a strong business network (Incorporated), and Thirdly, a collaboration between a Holding Company and Incorporated (Suryanto, 2010).

\section{Thought of the Muhammadiyah Contemporary Economic Movement}

As an organization that has a role and purpose to build or realize a progressive Islamic civilization. In the current era of globalization, Muhammadiyah likes or dislikes all the values it has, Muhammadiyah must be involved and take a more concrete role in economic activity. Therefore, it is necessary to realize a common understanding that a civil Society movement (such as; Muhammadiyah) has a role in building a progressive Islamic civilization and must have activities that are always in contact with economic activities, in a broader sense with all traits and the shape (Abbas \& Anhar, 2010). However, until now, Muhammadiyah still does not have a definite 
format of economic movements. Dialectics about the economic format of Muhammadiyah is still an interesting debate. There are three groups of thoughts about the format of the Muhammadiyah economic movement, namely; Incorporated Movement, Community Economic Empowerment Movement, and Comprehensive Economic Movement, which integrates between incorporated and empowerment.

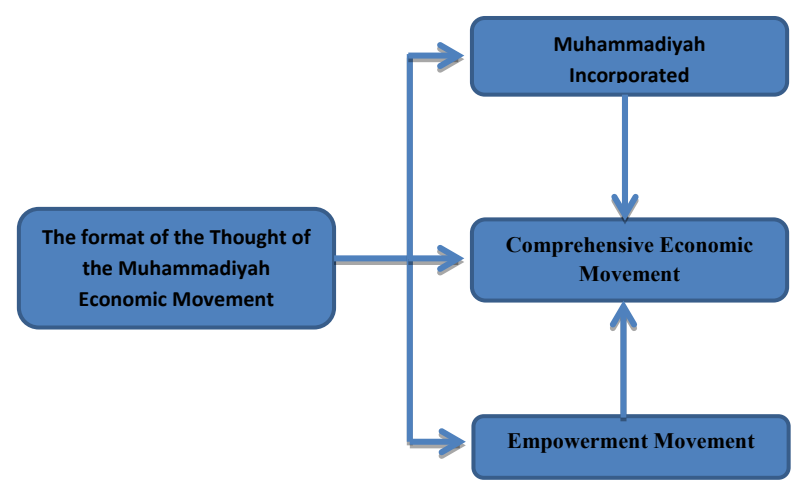

\section{a. Muhammadiyah Incorporated Movement}

The idea of the Muhammadiyah Incorporated originated from the workshop of the Forum of the Dean of the Faculty of Economics of the Muhammadiyah College (Fordek FE PTM) which was held on April 9-10, 2010, at the University of Muhammadiyah Malang. This idea was born from a concern about a large number of assets (charity businesses) owned by Muhammadiyah after growing and developing for a century, but not accompanied by professional asset management. Besides, the lack of synergy in relations between business charities also affects the slow and difficult development of these institutions. The amount of Muhammadiyah's business charity is so great, according to Mukhaer Pakkanna, (2010) will affect; First, management of the organization and administration is increasingly complicated. Second, the selectivity of management of resources is decreasing. Third, inefficiency and ineffectiveness in financial management. Fourth, control rope and quality assurance are increasingly difficult to control. Besides, according to I. B. Abdullah, (2010) that the challenges that must be faced along with the changing times and intense competition between the same institutions both domestically and abroad. Managing organizations in a professional way is a necessity if you do not want to see Muhammadiyah alienated from the situation or just as an audience.

Ijtihad in the management and development of business charity is urgently needed, considering there is no definite guideline in business charity governance. this is what causes the quality of Muhammadiyah's business charity to be left behind compared to similar institutions owned by the private sector or government (Birton, 2010). The dynamics of the development of science due to the revolution in the communication and information systems also lead to increasingly unique and diverse human needs, requiring organizations to be more adaptive, responsive and flexible (Mukhaer Pakkanna, 2010). Muhammadiyah which has thousands of educational institutions and hospitals and hundreds of universities, there will be demand and supply that has high economic value. Especially now that the business charity management paradigm in Muhammadiyah is more oriented towards obtaining residual income (Abbas \& Anhar, 2010). As a consequence of modern and progressive organizations, Muhammadiyah must respond to various challenges and developments. The management of the Muhammadiyah business charity must be distinguished from the core organizational management models, as well as autonomous organizations, but must be managed with a model of business management (corporate)(I. B. Abdullah, 2010).

From the above problems, resulting in the idea of managing business charity with the incorporated concept. Incorporated which is interpreted as a merger of management in strengthening networks both vertically and horizontally. Meanwhile, the meaning of the concept of Muhammadiyah Incorporated according to Mukhaer Pakkanna, (2010) is to strengthen the network of organizational structures, autonomous organizations, and business charities, by coordinating according to the fields and classification of activitiesAbbas \& Anhar, (2010) also explained that Muhammadiyah Incorporated plays a role and operates as a facilitator, mediator and consolidates the potential economic resources owned by Muhammadiyah systematically 
and integrated as managing a corporation or corporation to fulfill the demand and supply of Muhammadiyah Business Charity Units. However, Abbas \& Anhar, (2010) limit that Muhammadiyah Incorporated is not to build or form a business empire or company, Muhammadiyah Incorporated is also not to eliminate the rights of ownership or management authority over local economic resources. However, according to Abbas \& Anhar, (2010) it is possible, if the management of Muhammadiyah's economic resources are functioning properly and benefits can be felt, then in the future with the strength of capital and assets they have, Muhammadiyah Business Charity can change become a large corporation or corporation owned by Muhammadiyah.

To realize Muhammadiyah Incorporated, according to Abbas \& Anhar, (2010), I. B. Abdullah, (2010), Mukhaer Pakkanna, (2010) there are steps to realize Muhammadiyah Incorporated which can be concluded as follows;

1. Consolidate the vision, mission, and strategy of the movement in bringing together the steps to build the Muhammadiyah Incorporated

2. Instill the same awareness of the importance and usefulness of building a shared strength (corporation) towards the potential of Muhammadiyah, rather than moving on its own

3. Develop guidelines, build systems and instruments that can consolidate economic resources owned by Muhammadiyah that are spread and scattered in an integrated system through the corporate management process (Muhammadiyah Incorporated).

4. Socialize and implement the Muhammadiyah Incorporated system and guidelines

5. Restructuring, namely organizing the roles and core organizational relationships with autonomous organizations and business charity

6. Mapping and focusing on business charity.

7. Make internal alliances to realize Muhammadiyah Incorporated

8. Requires several pilot prototypes of Muhammadiyah Incorporated in a region.

\section{b. Economic Empowerment Movement}

The second group is the one that emphasizes the economic movement of Muhammadiyah in efforts to empower the community economy. Unlike the first group, this group views that the efforts of the Muhammadiyah to build holding and business groups such as establishing the Baitul Mal Wat Tamwil (BMT) and Cooperatives coordinated by the Economic Council (MEK) from the center to the branch will be trapped in interest and intervention in short-term business interests so it is difficult to separate the functions of Muhammadiyah as a socio-religious movement with business interests. According to $\mathrm{M}$. Fadjar, (2010) it is equally interesting for the Muhammadiyah movement to be in the vortex of the political and economic movements that are practical and pragmatic. Furthermore, (M. Fadjar, 2010) explained that the meaning of Muhammadiyah Incorporated was not on the economic management of Muhammadiyah's Charity Business but instead on the framework of the people's economic empowerment by synergizing all the energy of the organization.

M. Fadjar, (2010) explains that the Muhammadiyah Economic Movement is an economic movement oriented to efforts to empower and strengthen the economic community, Muhammadiyah economic movements should be initiated through social networks owned by Muhammadiyah by providing market opportunities, capital, business training, financial management information. Also, make business innovations that can cause binding and realizing togetherness among businessmen members of Muhammadiyah. Jatmiko, (2010) Affirms that the number of Muhammadiyah members is relatively large and widespread from urban to rural areas in most parts of the country. Some members are moderately educated and also move a lot in the business world. Networks with third parties are quite extensive and relatively easy to build cooperation. Muhammadiyah members have the potential demand for goods and services from the Muhammadiyah Business Charity that can support the people's economic empowerment movement.

The need to build cooperation in business ventures is also due to the waning of the spirit of togetherness and high individualism 
among Muhammadiyah citizens. So that gradually the business owned by members of Muhammadiyah experienced a setback and was unable to compete with big businessman, who in fact were non-Muslims. This reality had happened in the early days of the founding of Muhammadiyah. Where Muhammadiyah was founded by the great businessmen who succeeded in his day, but gradually their efforts were unable to compete with Chinese entrepreneurs who had a spirit of togetherness.

To build economic empowerment, Muhammadiyah did not depart from scratch. According to Rahardjo, (2000) Muhammadiyah has assets or resources that can be used as capital. The first asset is human resources, namely members of Muhammadiyah itself, both as producers, distributors, and consumers. Second, the Business Charity Institutions, that have been established, namely in the form of schools, universities, training institutions, polyclinics, hospitals, and orphanages. Third, the Muhammadiyah organization itself is from the center, region, region, branches, and branches. The same thing was expressed by E. S. Hamid, (2005) that the number of Muhammadiyah members was relatively large and was widespread from urban to rural areas in most parts of the country. Some members are moderately educated and also move a lot in the business world. Networks with third parties are quite extensive and relatively easy to build cooperation. Muhammadiyah members have the potential demand for goods and services from the Muhammadiyah charity that can support the people's economic empowerment movement. From here, according to Asy'Arie, (2000), Muhammadiyah needs to think professionally about its economic movement, through its market, so that it becomes the center of the people's economic empowerment movement. In this connection, it is necessary to develop and improve the quality of human resources owned by Persyarikatan Muhammadiyah in managing and developing business professionally, because in general, Muhammadiyah Business Charity is managed by its organizational activists, who are more patterned and charged in the social-religious dimension, and not yet fully managed by visionary professionals.
In this economic empowerment shutter, Mulkhan, (2000) emphasized that the need for full involvement and assurance of structural Muhammadiyah in economic empowerment. He described that providing opportunities for entrepreneurship development has naturally fostered productive economic activities for the lower classes of society, but if without the Muhammadiyah Structural guarantee, it would be like releasing a small child in the chaos of traffic in the middle of the city. Therefore, Supriyono, (2009) explains that technically the need for structural involvement in economic empowerment. There are several steps that must be made, namely; Firstly, the Economic Assembly in collaboration with the Basic and Secondary Education (Dikdasmen) and the Higher Education (Dikti) assemblies created a program to foster an entrepreneurial spirit in the younger generation of Muhammadiyah's cadres starting from school. Secondly, makes learning programs to spur entrepreneurial growth by providing training to teachers. Thirdly, spur the performance of entrepreneurs from Muhammadiyah cadres, both pioneering and established, by providing access to cooperation and information on market opportunities and financial access. Jatmiko, (2010) added that what was meant by the collaboration was to improve the capabilities and business of Muhammadiyah members and institutions, create markets for Muhammadiyah members and the general public, improve the ability to enter the market and increase flexibility to deal with environmental change.

\section{c. Comprehensive Economic Movement}

This third group believes that Muhammadiyah's economic movement needs to be built in two directions by integrating between Incorporated, through structuring and merging Muhammadiyah's business entities with economic empowerment of Muhammadiyah citizens. This group has the same understanding as the results of the 45th Muhammadiyah Conference in Malang which decided that the economic program is aimed at two objectives, namely; Institutional (Persyarikatan) and personal (people). What is meant by institutional targets is Muhammadiyah as an organization directly 
involved in economic activities that aims to explore the potential of financial resources for sustainability, while the personal objective is to improve the economy of the community or community members (Abbas \& Anhar, 2010). Whereas Juanda, (2010) uses the terms Structural and Cultural economic movements. What is meant by Structural Movement is to form a business charity in the economic sector in the form of a business-owned by Persyarikatan. While the cultural, economic movement is intended as a movement for economic empowerment of Muhammadiyah citizens.

In Sasono's, (1995) view, Muhammadiyah must sharply see the interaction between economic dynamics and the Da'wah movements that cannot be separated from each other. Because to answer the more relevant challenges caused by the phenomenon of the global world, it is necessary to have strategic steps to review and put in place a more appropriate strategy in the context of economic dynamics. The same thing was also conveyed by Andjasmoro, (2009) that Muhammadiyah was supposed to rethink more seriously the existing economic potential, to be able to be realized into a more tangible economic power for the Muhammadiyah. The many charitable businesses and business entities that exist are not necessarily claimed as the economic power of the Muhammadiyah. The economic strength of the community can only be built with a comprehensive movement system that is created, controlled and supervised by Muhammadiyah. Birton, (2010) emphasizes, that looking at the challenges of the future of the economy, what is needed is a formulation of patents on Muhammadiyah's economic Mazhab which includes a macro and micro economic framework and social development.

In this context, Andjasmoro, (2009) explained the need for structuring and unification (integration) of all institutional and personal business entities. At present, there are many businesses both in the real sector and in the financial sector that are owned by individuals belonging to the Muhammadiyah, owned by the private sector and who are jointly owned by the Muhammadiyah and members of Muhammadiyah. Then it is necessary to assemble into one economic power by establishing a business entity with the status of a legal entity that can become the center and economic network of the business complement. Besides, Andjasmoro, (2009) also highlighted the need to make a clear separation between the agencies that manage da'wah and those operating the business, as well as the managers of business enterprises not to be taken from the Muhammadiyah Management. However, the company management has the authority to supervise so that business entities do not get out of the flow of vision and mission. Meanwhile, in terms of increasing human resources Asy'Arie, (2000) explained that a business training concept that is integral to other training is needed, as part of the concept of Muhammadiyah's Cadre. Through this training concept, the quality of Muhammadiyah's resources to support the Muhammadiyah's economic development movement will be professionally developed. Without the support of professional business cadres, the corporate economic development movement will experience many difficulties.

Meanwhile, Raharjo, (2000) and Asnifati, (2009) emphasize the comprehensive economic movement by concluding that there are three main steps in the economic development of Muhammadiyah, namely; First, the establishment and strengthening of Muhammadiyah's business entities (BUMM), Second, guidance and assistance as well as network expansion for Muhammadiyah business people by conducting training, business meetings and mentoring for UMKM groups, Third, developing economic activities through existing charity businesses .

\section{CONCLUSIONS AND RECOMMENDATIONS}

There are three groups of thoughts about the dialectics of the thought format of the Muhammadiyah Economic Movement, although the Format of ideas from each group is not contradictory, namely; First, Incorporated, this thought arose as a result of the concern about a large number of assets owned by Muhammadiyah which has not been accompanied by professional asset management and lack of synergy in relations between business charities. Incorporated has a role and operates 
as a facilitator, mediator and consolidates the potential economic resources owned by Muhammadiyah systematically and integrated as managing a company or corporation. Second, Community Economic Empowerment through full structural involvement in economic empowerment by providing information on market opportunities, capital, business training, financial management and making business innovations in the younger generation of Muhammadiyah cadres starting from school to parents. Third, Comprehensive Economic Movements are those that integrate between Incorporated and empowerment. The target of this economic scale is institutional and personal. What is meant by institutional is Muhammadiyah as an organization directly involved in Economic activities that aims to explore the potential of financial resources for the sustainability of the Muhammadiyah, while the personal target is to improve the economy of the community or community members.

Muhammadiyah as a socio-religious organization that has an enormous asset, it is time to change the patterns of the old movement to suit the demands and developments. The historical closeness between da'wah movements and business activities as if they are two things that are inseparable and never obsolete in the times becomes an approach that should not be ignored as the most effective and appropriate approach in every era. The only thing that needs to be considered is the pattern of change and business development that always changes must be responded to and formulated into an effective approach. Through this approach, Muhammadiyah is expected to be able to release the people from slavery and destitution to realize progressive Islam so that Muhammadiyah must respond immediately to formulating the pattern of economic movements for the economic progress of the people.

\section{BIBLIOGRAPHY}

Abbas, A., \& Anhar, S. (2010). Membangun Gerakan Ekonomi Muhammadiyah melalui Pendekatan Korporasi. In N. Malik Fajar, I. Ulum, \& Widayat (Eds.), Gerakan Ekonomi Muhammadiyah; kajian dan pengalaman empiris. Malang: UMM Press.

Abdul Mu'in, J. (2017). Metode Islam Berkemajuan dalam Meningkatkan Produktivitas Amal Usaha Muhammadiyah. Sinar Sang Surya, 11(1), 49-60.

Abdullah, I. B. (2010). Reinventing Muhammadiyah: Ikhtiar Kecil Menuju Muhammadiyah Incorporated. In N. M. Fajar, I. Ulum, \& Widayat (Eds.), Gerakan Ekonomi Muhammadiyah; kajian dan pengalaman empiris. Malang: UMM Press.

Ahmad, G. (2015). Syariah Model Policy Cross Sectional Resources Management Muhammadiyah Charity Business in Developing Business. European Journal of Business and Management, 7(35), 189-195.

Alexander R. Arifianto. (2017). Islam with progress: Muhammadiyah and moderation in Islam (No. 213). RSIS Commentaries. Singapore. Retrieved from http://hdl. handle.net/10220/44024 Rights

Andjasmoro, A. (2009). Manhaj Gerakan Ekonomi. In N. Hamid (Ed.), Memberi dan Mencerahkan. Surabaya: Hikmah Press.

Asnifati, N. (2009). Pemberdayaan Ekonomi" dalam Najib Hamid. In N. Hamid (Ed.), Memberi dan Mencerahkan. Surabaya: Hikmah Press.

Asy'arie, M. (2000). Konsep Gerakan Pengembangan Ekonomi Persyarikatan Muhammadiyah. In A. Abdullah (Ed.), Meretas jalan baru ekonomi Muhammadiyah. Yogyakarta: Tiara Wacana.

Baidhawy, Z. (2015a). Lazismu and Remaking the Muhammadiyah's New Way of Philanthropy. Al-Jami'ah: Journal of Islamic Studies, 53(2), 387. https:/ / doi. org/10.14421/ajis.2015.532.387-412

Baidhawy, Z. (2015b). The Muhammadiyah's Promotion of Moderation. The American Journal of Islamic Social Sciences, 32(3), 69.

Birton, M. N. A. (2010). Tajdid dan Ijtihad Ekonomi Muhammadiyah Abad Mendatang. In N. M. Fadjar, I. Ulum, \& Widayat (Eds.), Gerakan Ekonomi Muhammadiyah; kajian dan pengalaman empiris. Malang: UMM Press. 
Elhady, A. (2017). Islamic Reform Movement In Indonesia : Role Of Muhammadiyah In Social Empowerment. International Journal of Academic Research in Business and Social Sciences, 7(8), 340-350. https:// doi.org/10.6007/IJARBSS/v7-i8/3234

Hamid, A. (2017). Muhammadiyah and da'wah in social welfare. In Toward Community, Environmental, and Sustainable Development (Vol. 6, pp. 1-2). University of Muhammadiyah Jakarta, Indonesia.

Hamid, E.S. (2005). VideSuara Muhammadiyah. Suara Muhammadiyah, 13.

Jacalyn Sherriton, \& Stern, J. L. (1996). Corporate Culture: Removing the Hidden Barriers to Team Success. New York: Amacom.

Jatmiko, R. D. (2010). Menumbuhkan Gerakan Ekonomi dan Bisnis Melalui Partnership Stratejik Amal Usaha Muhammadiyah. In N. M. Fadjar, I. Ulum, \& Widayat (Eds.), Gerakan Ekonomi Muhammadiyah; kajian dan pengalaman empiris. Malang: UMM Press.

Jinan, M. (2011). Dinamika Pembaruan Muhammadiyah: Tinjauan Pemikiran Keagamaan. Tajdida, 9(1), 1-16.

Juanda, A. (2010). Membangun Etos Ekonomi Kelas Menengah di Muhammadiyah. In N. M. Fajar, I. Ulum, \& Widayat (Eds.), Gerakan Ekonomi Muhammadiyah; kajian dan pengalaman empiris. Malang: UMM Press.

Karim, R. (1995). Realitas Jati Diri Muhammadiyah dipertanyakan. In Kuntowioyo (Ed.), Intelektualisme Muhammadiyah Menyongsong Era Baru. Bandung: Mizan.

M. Fadjar, N. (2010). Strategi Gerakan Ekonomi BisnisMuhammadiyah. In N. M. Fajar, I. Ulum, \& Widayat (Eds.), Gerakan Ekonomi Muhammadiyah; kajian danpengalaman empiris. Malang: UMM Press.

Mukhaer Pakkanna. (2010). Muhammadiyah Incorporated: Sebuah Keniscayaan di Abad Kedua. In N. M. Fajar, I. Ulum, \& Widayat (Eds.), Gerakan Ekonomi Muhammadiyah: kajian dan pengalaman empiris. Malang: UMM Press.

Mulkhan, A. M. (1990). Pemikiran K.H, Ahmad Dahlan dan Muhammadiyah dalam Prespektif Perubahan Sosial. Jakarta: Bumi Aksara.
Mulkhan, A. M. (2000). Moral kenabian: paradigm intelektual pembangunan. In A. Abdullah (Ed.), Meretas jalan baru ekonomi Muhammadiyah. Yogyakarta: Tiara Wacana.

Nakamura, M. (2012). The Crescent Arises over the Banyan Tree: A Study of the Muhammadiyah Movement in a Central Javanese Town $c$. 1910-2010. Sin- gapore: ISEAS.

Njoto-Feillard, G. (2014). Financing Muhammadiyah: ?e Early Economic Endeavours of a Muslim Modernist Mass Organization in Indonesia (1920s-1960s). STUDIA ISLAMIKA, 21(1), 1-46.

Radjasa. (2016). Moslem Community in Borobudur Centtral Java Respose of Muhammadiyah Community to Economic Change from Agriculture to Tourism. International Journal of Education and Social Science, 3(12), 51-58.

Rahardjo, D. (2000). Quantum Leap Ekonomi Muhammadiyah 2000 Revitalisasi amal usaha Muhammadiyah. In E. S. Hamid (Ed.), Rekonstruksi Gerakan Muhammadiyah Pada Era Multi Peradaban. Yogyakarta: UII Press.

Raharjo, D. (2000). Format dan Strategi Pengembangan Ekonomi Muhammadiyah dalam melenium ke tiga. In Meretas jalan baru ekonomi Muhammadiyah. Yogyakarta: Tiara Wacana.

Rahman, H. (2017). Peran Organisasi Keagamaan Muhammadiyah Dalam Modernisasi Ekonomi Masyarakat Islam Di Kota Pekanbaru (Tahun 2017). JOM FISIP , 4(2), 1-15.

Rambe, R. (2018). Gerakan Ekonomi Islam Pada Era Pra Kemerdekaan. At-Tawassuth, 3(1), 529-553.

Sasono, A. (1995). Muhammadiyah dan pemberdayaan rakyat. In A. Ma'ruf (Ed.), Muhammadiyah dan Pemberdayaan Rakyat. Yogyakarta: Pustaka Pelajar.

Setyawan, D. (2013). Analisis Hubungan Ijtihad Dan Tajdid Pemikiran Ekonomi Terhadap Perkembangan Usaha (Studi kasus Pada Amal Usaha Organisasi Masyarakat Muhammadiyah). Jurnal EKONOMI ISLAM, 2(1), 105-134.

Setyawan, D. (2017). Moving Ijtihad And Tajdid On Amal Usaha Muhammadiyah (AUM) 
In Building The Civilization Of Islamic Economy. ADDIN, 11(1), 77-100.

Supriyono, I. (2009). L1MH. In N. Hamid (Ed.), Memberi dan Mencerahkan. Surabaya: Hikmah Press.

Suryanto, R. (2010). Merancang Ulang Sisten Akuntansi Amal Usaha Muhammadiyah menuju Muhammadiyah Incorporated. In Nazaruddin Malik Fajar, I. Ulum, \& Widayat (Eds.), Gerakan Ekonomi Muhammadiyah; kajian dan pengalaman empiris. Malang: UMM Press.

Syahbudi. (2003). Gerakan dan Pemikiran Sistem Ekonomi Islam di Indonesia. Hermeneia: Jurnal Kajian Islam Interdisipliner, 02(02).
Wahjono, S. I. (2012). Strengthening Family Business in the Muhammadiyah To. In International Conference on Strengthening The Moslem Community in the South Asia Region toward ASEAN Community 2015 University of Muhammadiyah Malang Indonesia 14-16 June 2012 (pp. 1-20).

Wahyuddin, M. (2010). Retrospeksi pemikiran muhammadiyah sebagai gerakan ekonomi. Tajdida, 8(1), 30-34.

Zulfikar, A., \& Azhar, A. (2018). Persyarikatan Muhammadiyah Merespon Tantangan Dunia Kerja dan Kompetisi Global. In Kolokium Pemikiran Kaum Muda Muhammadiyah (pp. 1-12). https://doi. org/10.31227/OSF.IO/5CAVB 